\title{
A Postmodern Viennese Narrative: Lilian Faschinger's Wiener Passion
}

\author{
EVA KuTTENBERG \\ Penn State Erie, The Behrend College
}

\begin{abstract}
Es fließen ineinander Traum und Wachen, Wahrheit und Lüge.

Sicherheit ist nirgends.

Wir wissen nichts von anderen, nichts von uns.

Wir spielen immer, wer es weiß, ist klug!
\end{abstract}

-Arthur Schnitzler, Paracelsus

\begin{abstract}
Since the 1990s historical Vienna has figured prominently in Austrian fiction by emerging and established authors alike: Arnold Geiger's (1968- ) Es geht uns gut (2005); Eva Menasse's (1970- ) Vienna (2005); Lilian Faschinger's (1950- ) Wiener Passion (1999) and Stadt der Verlierer (2007); Doron Rabinovici's (1961- ) short story collection Papirnik (1994); Robert Schindel's (1944- ) Gebürtig (1992), made into a film of the same title in 2002; and parts of Robert Menasse's (1954- ) Selige Zeiten, brüchige Welt (1991). ${ }^{1}$ These diverse works convey family history; engage multiethnic past and present Vienna; and with a great sense of humor and irony, comment on the inherited Habsburg legacy and (except for Wiener Passion) on National Socialism. ${ }^{2}$ Characters negotiate pre- and postwar identities and ethnicities in interesting ways, through encounters that challenge them. The narratives balance the bright and dark sides of Austria's rich culture and history by drawing on music, architecture, and a diverse character ensemble as well as on anti-Semitism, misogynism, and xenophobia. ${ }^{3}$ Except for Wiener Passion, which indulges in detailed descriptions of Viennese places, the majority of these texts are set in a mysteriously "masked" Vienna only identifiable by select historic landmarks or locales frequented by the protagonists.
\end{abstract}


Already in her first novel, Die neue Scheherazade (1986), exploring Austro-Persian relationships, Lilian Faschinger had her protagonist, Hedwig Moser, escape into a world of imagination, draw on popular myths, and engage in contemporary cross-cultural dialogue - all elements that have become staples of Faschinger's literary practice along with her most salient conscious retelling of stories (in Scheherazade's case, the Tales of 1001 Nights). My focus here will be on her novel Wiener Passion, also published under the title Vienna Passion, which critically revives the epic Viennese Stadtroman. ${ }^{4}$ This genre originated in the early 1900s with Arthur Schnitzler's Der Weg ins Freie (1908), to be followed by Robert Musil's Der Mann ohne Eigenschaften (1930, $1933,1943)$ and postwar writings including Heimito von Doderer's Die Strudlhofstiege (1951), Ingeborg Bachmann's Malina (1971), and Elfriede Jelinek's Die Klavierspielerin (1983). Fin-de-siècle literature, for instance Schnitzler's Der Weg ins Freie, addressed ethnic tensions in an era of heightened Jewish assimilation and anti-Semitism. Moreover, Schnitzler offered a nuanced reading of Vienna's amusement park Prater as a democratic playground for all classes, but a one-dimensional view of the Vorstadt as idyllic getaway for the upper bourgeoisie. ${ }^{5}$ His social commentary focused on the middle class, whereas Else Feldmann's recently discovered reportage Der Leib der Mutter (1924), originally published in installments in the Wiener Arbeiter-Zeitung, showed the poverty-stricken side of Vienna. Perhaps not surprisingly, women writers of the 1920s, Veza Canetti among them, were at the forefront in addressing social and gender issues from disability to criminal acts and prostitution.

In Wiener Passion, thematically, Faschinger picks up where Schnitzler, Feldmann, Canetti, and others left off, yet turns to a postmodern aesthetic practice of "historiographic metafiction," which for Linda Hutcheon entails a "theoretical self-awareness of history and fiction as human constructs" and critically engages in "rethinking and reworking the forms and contents of the past." In the novel, set in Vienna in the 1990s and extensively describing the 1890s, fact and fiction, along with past and present, happily coexist, interact with, and comment on each other. This effect is enhanced by narrative strategies of mirroring and recasting aspects of the historical part of the novel in its contemporary setting and thereby providing alternate views with a particular focus on gender. Doubling occurs in several domains: geographically via a shared set of locations such as landmarks, commercial spaces, and cultural venues along with gestures, attitudes, and behavior patterns. At the level of characters, the female protagonists Rosa Havelka and Magnolia Brown are established as doubles since both are newcomers to a city defined by tradition and as opposites when it comes to class, education, and religion. Doubling also happens with narrative patterns in a novel composed of narrated monologues and depicting a family history across four generations and two continents. The majority of the text amounts to a "historicized fictional biography"-a definition borrowed from Dorrit Cohn ${ }^{7}$ — chronicling Rosa Havelka's hardships 
as an orphaned Czech immigrant in imperial Vienna and raises questions of subjectivity and its systematic annihilation. ${ }^{8}$ The other part, only half as long, reads like a highly amusing postmodern novel combining traits of a Künstlerroman and a love story of opposites that attract when the New York transplant, actress Magnolia Brown, falls in love with the erratic Viennese voice teacher, Josef Horvath. The novel as a whole is an astute, ironic sociocultural commentary on past and present Viennese life, addressing issues of gender, class, race, sexuality, social inequality, religion, and canonical and popular art. Faschinger readily assumes the double role of historiographer and fantastic novelist narrating the complexities of the postmodern via a "parodic interrogation of history and revisitation of the past." She clearly avoids a nostalgic return to the past and remains resolutely historical and political in depicting the fate of Rosa Havelka, whose abiding quest to serve-a tradition passed on from her mother, a servant, and enhanced by religious education-leads her into all sorts of adventures..$^{10}$ To a certain extent, the account of her youth, education, and short adulthood is a reversed Bildungsroman, detailing every passage of her life, which becomes more hopeless with every step she takes. ${ }^{11}$

So far, critical analysis has focused on the historic aspects of Rosa's ordeal in the late 1800s, exposing misogyny in the justice system, the medical profession, and the Catholic Church. ${ }^{12}$ Such an approach highlights the vividly painted counterimage to Vienna as celebrated haven for the arts:

Wien sei nicht die Stadt der Musik, der Literatur, der Malerei und der Baukunst, als die sie fälschlicherweise dargestellt werde, [ . . ] Wien sei ein Hexenkessel, eine riesige Arbeiterstadt, in der die Menschen ums Überleben kämpften, in der man schufte, bis man umfiele, und dafür einen Hungerlohn erhalte, wo man zusehen müsse, daß man nicht binnen kürzester Zeit im Obdachlosenasyl endete. ${ }^{13}$

Granting the peripheral female figure a literary voice is of course important, but more is at stake in Wiener Passion than reiterating Karl Kraus's perception of imperial Vienna as hopelessly rigid and xenophobic, especially since the novel's distinct time frames are not constructed separately as narrative frame and main plot but as parallel alternating texts. While the historic script relies exclusively on Rosa, as if to lend her voice subjective authority, the contemporary one operates with alternating narrative voices between Magnolia and Josef, thus giving a dual perspective of newcomer and Viennese resident. Neither part has subtitles, only numbered chapters, which underscores their equal status in the narrative and leaves it up to the reader to follow the sequence of the novel or focus on Vienna in either 1900 or 1990-a choice made easy by different typefaces in the English version. Since nineteenthand twentieth-century Vienna are present "in terms of a series of overlapping literary, popular fictional, artistic and historical texts," I suggest that the novel enacts a paradigm shift in narrating the history-laden city by juxtaposing 
characters from the 1890s who seek "to gain one's footing in the metropolis" and characters from the 1990s who "comprehend transience itself as the "essential." ${ }^{14}$ Faschinger depicts both heroines in settings that require extraordinary adaptability, and their choices are motivated by economic necessity, Rosa's even more so than Magnolia's. Rosa, fixated on tradition, reinvents herself from a student in a convent to a maid, mistress, and wife, from an inmate of a psychiatric ward to a street musician and murderess of her husband, a serial rapist. In every single one of these circumstances she finds herself trapped and is either violently catapulted out of a dependence structure or breaks free only by resorting to radical measures, including a suicide attempt. Her efforts end in terrible failure. Magnolia Brown, the happy product of the 1960s American dream of free love in New York's Central Park (conceived under a magnolia tree at the peak of civil rights demonstrations and interracial relationships), deliberately situates herself in the city and exemplifies an attitude of transience. She swiftly adjusts to new situations, whereas her newfound love Josef is initially firmly anchored in the past. Magnolia's gentle intervention, however, helps him gradually shed his past and live in the moment.

Faschinger's postmodernism depicts the world in relation to artistic form to effectively raise these ideological issues and refers to Peter Brook's Shakespeare productions casting "Schauspieler unterschiedlicher ethnischer Zugehörigkeit" (WP 46). Attractive African American Magnolia is hired for the role of Anna Freud by the producer of a Broadway musical, who enthusiastically explains: ${ }^{15}$

Was spreche dagegen, ein Musical über Sigmund Freud auf die Bühne zu bringen, in dem nur farbige Darsteller aufträten, nichts spreche dagegen, ein solcher Gedanke sei vollkommen einleuchtend, seien nicht die Juden die Schwarzen Europas, die Afroamerikaner der Alten Welt, ließe sich ihre Marginalisierung, ihre Ausgrenzung nicht mittels dieses Kunstgriffs auf das Überzeugendste repräsentieren? [ . . ] es ginge um eine uneingeschränkte Parteinahme für die Opfer, die Sündenböcke, die Unterdrückten und Ausgeschlossenen dieser ungerechten Welt. (WP 46, 50)

The producer, who instantly becomes her lover, undermines his noble political agenda by showering Magnolia with racially charged nicknames: "köstliches Kaffeeböhnchen, berückendes Brownie, moroses Mohrenköpfchen, mein süßes Sachertörtchen, mein schmollendes Schokoladeneclair" or "nußbraunes Negerpüppchen" (WP 48, 120, 552). Lacking other offers, she accepts the role and spends a few weeks in Vienna studying music to prepare for the engagement. Besides training her vocal cords, the trip gives her an entirely new perspective of female victimhood when she discovers Rosa Havelka's manuscript at her host's home.

The following analysis of Wiener Passion echoes Faschinger's selfunderstanding as a postmodern writer privileging the imaginary and taking 
pleasure in designing complex networks of plots, subplots, and characters along with making poignant references to high and popular culture. ${ }^{16}$ After situating the novel in a postmodern aesthetic and outlining its complex texture, I shift the focus to analyze space and time as discursive urban practices. I draw on Michel de Certeau's seminal essay "Walking in the City"17 to examine urban space, juxtaposing private homes that shield the individual from the outside world with transgressive public spaces, including the street, cemeteries, and subway platforms. In reference to temporal structure, Faschinger fastidiously revisits the historic past in order to contrast, compare, and intertwine it with the present and thereby narratively maps the complexities of "historiographic metafiction." I conclude with examples of witty temporal and spatial conflations and intersections that render transience as a typical postmodern trait.

\section{Postmodern Text and Texture}

Wiener Passion is an extravagant fantasy of mysteriously entangled plots couched in the mundane realism of everyday life. Interacting urban maps capture the respective experiences of visitor, resident, and immigrant. Magnolia, with energy and spontaneity, draws a touristy cultural map marked with her visits to prominent sites from Stephansdom and Fiaker to Heurigen, and Freudmuseum. En route to her voice lessons, she passes by the Secession, "einem von einer goldenen Kugel gekrönten Tempel" (WP 71); a sociological panorama from residents' racism to xenophobia or innocent surprise about her "exotic" looks and charming, fluent Viennese thanks to her Austrian heritage; and insights into homes and lifestyles. Arriving in Vienna, she is impressed by the sleek marble tiles at the airport, a taxi ride past stunning architecture, and the narrow streets around her aunt's home. With her suitcase in one hand and the heel of her shoe, which came off while she walked on the cobblestone street, in the other, she meets her eighty-year-old Aunt Pia, who extends a heartfelt welcome:

Hübsches Kind, hübsches Kind, kicherte sie, aber schwärzer, als sie sich mich vorgestellt habe. Sie hätte gedacht, ich sei hellbraun, hellbraun wie Milchkaffee, eventuell noch mittelbraun wie eine Haselnuß, aber so dunkel, nein, so dunkel, die arme Flora. (WP 36)

The newcomer's map interacts with that of the resident Josef Horvath, whose grand entrance into Viennese urban splendor is rather modest: as a regular at the St. Mary Magdalene Pharmacy, where both his hypochondriac and his social needs are met. Josef's social world revolves around his residence in the building where Franz Schubert died, the so-called Death House; the Café Anzengruber; the restaurant Zur Goldenen Glocke; the newspaper and tobacco store with a decidedly social function as "ein Ort der Begegnung"-and for leisure, the grounds of the psychiatric hospital Baumgartner Höhe (WP 13). 
His favorite refuge from the urban hustle and bustle are the royal Habsburg burial place, Kapuzinergruft, and cemeteries; his most dreaded excursion takes him to the auction house Dorotheum, where sellers get rid of items with a past and buyers seek them precisely for their past.

Rosa Havelka's experience of the 1890s as a penniless young girl complements these two other cultural maps. At the mercy of all sorts of urban elements, she personifies the "marginalized, peripheral figure of fictional history," traditionally doubly silenced: an illegitimate child of a servant and employer whose future is to be another domestic and sexual servant, and finally unemployed, homeless, and criminal. ${ }^{18}$ Captivated by the action-filled narrative, Magnolia makes further inquiries and discovers that Rosa was her great-grandmother. From a strictly historical-documentary perspective, the biography's validity is questionable for several reasons: the manuscript had been entrusted to Beata Maria Postl, a member of the community of the Sisters of the Good Shepherd, who readily acknowledges editing it to promote Christian morals; it is unusually eloquent for an author with rather basic education; and it includes the puzzling harsh punishment of hanging for a murderess in 1900 Vienna. However, these reservations are beside the point for Faschinger's "postmodern concern for the multiplicity and dispersion of truth(s)."19 Wiener Passion is not, and is not intended to be, a reliable account of Rosa's tribulations that can be verified historically.

Faschinger's ironic dialogue, with Vienna's past as a defining element of its present, is firmly anchored in the urban map with its splendid landmarks, including the Habsburg residences Schönbrunn and Hofburg, and its countless names of streets, stores, and churches pointing to a long history of Catholicism. Weaving an eloquent web of interacting narrative strands, she produces "an irreducibly plural text - made up of a range of competing voices." ${ }^{20}$ To sustain a viable dialogue among them, she constructs literary/linguistic, commercial, cultural, and institutional points of confluence-some uniquely Viennese, from Prater to Musikvereinssaal and Zentralfriedhof, and others universal and nondescript, from shops to subway platforms ${ }^{21}$ Whereas a poetics of concrete, steel, and glass is largely confined to Vienna's periphery (e.g., Unocity or Milleniumtower), its downtown architecture resembles a textbook history, leaving the masses mute. Faschinger gives them a voice with a backstage look at the imperial Hofburg and its hundreds of servants. She most effectively makes the marginal visible in the postmodern urban literary imagination through her vivid description of being homeless in the 1890s and seeking shelter in the sewer system. Thereby she critically addresses the unresolved, only recently discussed paradoxes of modernity - an era when "new boundaries between high and low, between aristocrat and rag-picker, were there simultaneously established and transgressed." 22

Given the multitude of issues raised in Wiener Passion, and as MariaRegina Kecht convincingly shows, Faschinger's polemic against institutions is 
powerful in and of itself. Equally intriguing, however, is her unique presentation style privileging a postmodern aesthetic that evokes "ideas of irony, [ . . . ] playfulness, parody, hyper-reality and simulation." ${ }^{, 23}$ Echoing select arguments from Brian McHale's Postmodernist Fiction ${ }^{24}$ her accomplished style leads to a "suspension of belief as well as disbelief," throwing the reader into a state of "ontological uncertainty," especially when describing "a plurality of universes" (McHale 27-33). Her mockery and parody of the past leaves the reader in a quandary, not knowing "who or what in a text they can believe or rely on." ${ }^{25}$ And "this uncertainty about the reality of the fictional world is more than just artistic playfulness" because it shows how the novel engages with cultural and sociohistorical questions. ${ }^{26}$

Stylistically, the novel is a tour de force of rigorously composed sentences regardless of the characters' social status or education, as the reviewers Rothschild and Weinzierl noted. ${ }^{27}$ The elegant, eloquent, and exceedingly measured tone heightens the effect of numerous rather absurd encounters, actions, and reactions. Skillfully blurring the notion of narrated events and social structures and narrating events as characters experience them not only levels differences in their respective identities but also lessens the time gap of one hundred years, as if to underscore continuity without necessarily obscuring subtle changes. Faschinger's extremely self-conscious style of writing is a mix of "enzyklopädische Detailversessenheit" (Rothschild) and "üppige Wortpölster" (Haas) and has earned her a reputation as Austria's "fabulierfreudigste Schriftstellerin" (Weinzierl). ${ }^{28}$ In her interview with Ellie Kennedy, she explains the "excess of indirect speech in order to create an alienation effect." 29 Actually the entire novel should be read as a parody of "certain familiar and overtly conventionally plotted forms," from psychoanalysis to religious mysticism, from love story to memoir. ${ }^{30}$ Racially inflammatory remarks urging Magnolia to return to her black African homeland mimic the style of Thomas Bernhard, a major inspiration for Faschinger. ${ }^{31}$

As is typical in historiographic metafiction, in the novel "historic personages take on different, particularized and ultimately ex-centric status." 32 Besides the famous Austrian empress Elisabeth, nicknamed Sisi, historical figures include Kronprinz Rudolf, desperately seeking a suicide companion. Seemingly ordinary citizens from the late 1800s also show rather peculiar character traits: a paranoid psychiatrist accuses Sigmund Freud of plagiarizing his ideas; a poet awaiting literary acclaim writes his poetry on his lover's skin; a humble workman suffering from a compulsive obsession with Sisi sexually assaults women with similar physical features and hairstyles; and a sadomasochistic religious fanatic displays radically different personalities in private and in public.

With their unconventional lifestyles, the characters from the 1990s are a perfect match. Now almost exclusively confined to her home, eighty-yearold Aunt Pia's social world is limited to occasional chores performed by 
the Bosnian caretakers in her building. Josef is caught in a peculiar harem of women who are "fürsorglich, geduldig und ausgeglichen" (WP 127): his neighbor and retired pastor's assistant Fräulein Haslinger; the florist; and the pharmacist from the St. Mary Magdalene Pharmacy. The most down-to-earth person happens to be Magnolia from Manhattan's East Village. In sum, an odd mix of characters narrate postmodern Vienna: the elderly who barely leave their homes and then only accompanied by their beloved dogs, immigrants struggling to make ends meet, women whose lives are consumed by needlework or religious meditation, and teachers with unorthodox methods. Partly because of these "oddballs" and a diverse ensemble of secondary characters but also because of prolific references to classical music, from Franz Schubert and Gustav Mahler to the Wiener Sängerknaben, this polyphonic novel's original title was Wiener Stimmen. ${ }^{33}$

\section{Spatial and Temporal Urban Practices and Networks}

In his thought-provoking essay "Walking in the City," Michel de Certeau develops an intriguing theory about the urban and reads select "spatial practices" as speech acts. ${ }^{34}$ Faschinger focuses on three urban signifying practices: street signs and proper names as literary-cultural material; public space and residential buildings as sites of confrontation, discrimination, and violence against women and minorities, but also as places for respectful conversation and intimacy; and the home as a shrine commemorating diverse absences.

Meticulously spelling out exact street addresses, "fünfter Wiener Gemeindebezirk, Schönbrunnerstraße vierundfünfzig, zweiter Stock, Tür achtzehn," is a duplicitous, culturally and historically revealing, and narratively deceptive strategy (WP 23). While such an address alludes to stilted bureaucracy, it also points to the Viennese solution of the housing crisis in the 1920s: the labyrinthine public housing complex, the Gemeindebau accommodating up to 4,000 people, made it absolutely necessary to provide additional information, such as "Stiege, Stock, and Tür." Excessive listing of proper names of churches, markets or streets, for instance Stoß-im-Himmel Gasse, Jasomirgottgasse, Schleifmühlgasse, Domgasse, Blutgasse, Lindengasse, Kettenbrückengasse, Siebensterngasse, Stiftgasse, Mondscheingasse, Sensengasse, Lazarettgasse, and dozens more, familiarizes those readers who are passionate cartographers with Vienna. For the most part, such specificity does not guarantee geographic orientation, but it lends the narrative authenticity and produces text, if only disjointed scraps that destabilize the signifying function. Thus it underscores an important aspect of postmodern writing by creating a dynamic dialogue between reality and fiction, incorporating Vienna's city map into an inherently imaginary narrative.

In The Urban Revolution, the theoretician Henri Lefebvre defines the city as a profoundly differential space with social practices including everydayness (140). Faschinger's focus on day-to-day interaction inevitably maps 
zones of conflict and Magnolia's puzzling encounters with Viennese capable of blatant prejudice and racial and sexual harassment. At a subway stop, an elderly lady tells her dog, "faß die Negerin, faß" and supports her outrageous comment with "ihr Vater, der als Wirklicher Hofrat in den Ruhestand getreten sei, habe immer gesagt, er werde es gottlob nicht mehr erleben, er nicht, aber sie werde es noch erleben, daß unser gesegnetes Land von den Negern aus Afrika erobert würde, Quadratmeter um Quadratmeter" (WP 72). Similarly, Aunt Pia misses no opportunity to launch her attacks:

daß der Prozentsatz der sich in Wien niederlassenden Ausländer und Ausländerinnen schwindelerregende Höhen erklettere, was zusammen mit ihrer $[\ldots]$ Schwerhörigkeit, ein Grund sei, weshalb sie ihre Wohnung so gut wie nie verlasse, man müsse ständig damit rechnen, unmittelbar nach dem Hinaustreten auf die Blutgasse, auf die Domgasse, von einem Montenegriner, einem Slowaken, einem Rumänen oder gar einem Schwarzen niedergeschlagen und seiner Ersparnisse beraubt zu werden. (WP 387)

Faschinger subverts the cliché of foreigners perpetrating crimes by making the reported rape victims foreigners deliberately chosen by an "extreme right-winger." After attacking and raping a young Vietnamese nurse, the criminal contacts the police to declare: "langsam, aber sicher übertreffe die Zahl der Elemente minderwertigen Geblüts jene der reinrassigen Österreicher, da die zuständigen Behörden sich nicht zur Ausweisung dieser fremden Subjekte entschließen könnten, müßten Menschen wie er, die ihr Land liebten, zur Selbsthilfe greifen" (WP 351). Ultimately Magnolia is a winner instead of a victim when she snatches up Josef, in Aunt Pia's words one of the most eligible bachelors in Vienna. Ironically, Muttersöhnchen Josef turns a city which is "alles andere als gastfreundlich, ja offensichtlich höchst fremdenfeindlich" into a place of human possibilities (WP 122). But Faschinger cautions against deceptive blissful harmony when Josef plans his future home with Magnolia and claims the living room for his singing lessons while graciously letting her have the broom closet as an ideal rehearsal space.

Perhaps one of the most revealing cultural territories is Vienna's main cemetery, the Zentralfriedhof, where a collective (mythical) past, manifested in the beautifully maintained and decorated graves of the musicians, coexists with individual pasts of citizens long forgotten. Aunt Pia turns it into a contested site of ethnicity when she expresses deep regrets about how it is open to all religions:

man frage sich, was die jüdischen Toten hier verloren hätten, wie ordentlich gepflegt der christliche Teil wäre und wie vernachlässigt der jüdische $[\ldots]$ Eine Schande für national und katholisch empfindende Österreicher deutscher Muttersprache, habe der Major bei ihrem Spaziergang immer gesagt. (WP 67)

Implied in this outrageous comment is the near absence of Jewish life in postwar Vienna-a historical fact Aunt Pia fails to grasp, since for her the Dr. Karl Lueger Memorial Church, named after the early twentieth-century 
anti-Semitic mayor, "einem aufrechten und patriotischen Wiener Menschen" remains of great importance (WP 67). In the same style of the elderly lady's racial attacks, Aunt Pia legitimates her claim by drawing on an authority figure, her late husband. Her statement also exemplifies how history is preserved in the collective memory of its citizens and of a nation and mirrors popular opinion. In a similar vein, Josef's building is a contested site for nationality: "die Mietergemeinschaft [habe] sich außerdem geschlossen gegen die Zumutung der ständigen Anwesenheit einer ethnisch fremden Gruppe im Sterbehaus Schuberts ausgesprochen, der doch eine zutiefst deutsche Musik komponiert habe" (WP 22). This attitude forced the non-Austrian tenants to vacate what then became Josef's apartment and will soon also be Magnolia's new home.

Similarly, Aunt Pia's home, a terribly overheated "düstere Puppenhaus," enshrines the past. It is populated by dolls standing, sitting, and lying everywhere: "Dutzende von Puppen [ . . ] , die mich vom Bett und vom Nachttisch, vom Fenstersims, vom Schreibtisch und von einer alten Truhe aus mit großen runden Augen ansahen. Sogar zwischen den Blättern eines Philodendrons spähten sie hervor" (WP 38). Decades after her daughter Wilma died at a very young age of carbon monoxide poisoning caused by cracked tiles of the spectacular fireplace, the Biedermeier Kachelofen, Pia continues to tend to a vast doll collection by knitting them new outfits. She has kept Wilma's room intact and even preserved her dresses with mothballs; she generously offers them to Magnolia as distinctly feminine and proper attire for accompanying Josef to his musical treat for her-the Sunday mass with the world famous Vienna Boys Choir. Out of sight but still accessible is yet another relic from the past-Rosa's manuscript. While these ghosts don't bother Magnolia in the apartment, they begin to spook her when she descends into the dark cellar to fetch coal.

Josef lives in the same apartment building as Schubert did prior to his death, which the city of Vienna turned into a museum, thereby converting the former private home into a public shrine commemorating the past. De Certeau poignantly notes: "It is striking here that the places people live in are like the presences of diverse absences." ${ }^{35}$ While the building's history is guarded by an ambitiously knitting woman, Josef, literally enveloped by his own history and surrounded by memorabilia, particularly portraits of his mother, is getting rid of it piece by piece, selling off items he inherited and collectibles from his childhood and teenage years. Magnolia's first impression of Josef's home is overshadowed by him nursing his hypochondriac health problems with large white sheets hanging on a line in the living room; a well-stocked assortment of herbal teas; and finally a hot footbath while she dutifully prepares his favorite violet-leaf tea. He personifies the legacy of the ailing Habsburg empire in the early 1900s.

Rosa's, Magnolia's, and Josef's accounts pay scrupulous attention to the particulars of everyday life, from detailed descriptions of homes to two 
other essentials, clothes and food, for "man will be quotidian or will not be."36 In terms of clothing, fashionably dressed Magnolia in high heels, tight-fitting pants, and sweaters lives up to the Viennese preoccupation with style and dismissal of casual dress, whereas Aunt Pia and Josef make a sharp first impression by welcoming her in shabby bathrobes and dirty slippers. Faschinger's irony is relentless when it comes to food and food preparation, such as Aunt Pia's favorites of tripe soup, calf's brain, and pig's head. ${ }^{37}$

As Faschinger interlaces Vienna of the 1890s with Vienna of the 1990s, she refrains from "mortifying the past" and instead endows places steeped in tradition with new meaning and functionality, both literally-for example, as characters jog in the park of castle Schönbrunn - and metaphorically, as Magnolia and Josef plan to name their offspring Sisi, after his mother and the legendary Empress Elisabeth. This method of opening up the past to the present is also applied to world-famous Austrian composers. Mahler's Kindertotenlieder and above all Schubert's Winterreise cured the sickly young Josef and created a lifelong bond that explains his desire to seek an apartment in Schubert's Sterbehaus after carefully researching and exhausting all other options connected to the composer's life. And of course, Magnolia's first assignment for her voice lesson is a Schubert song.

De Certeau laments the fact that "unlike Rome," New York continually reinvents itself and "has never learned the art of growing old by playing on all its different pasts." ${ }^{38}$ It could seek inspiration from Vienna, which dwells in its distinct cultural past. With a great sense of humor, Faschinger critiques the Viennese phenomenon of dressing up and commodifying its history. Josef's precarious financial situation forces him to sell a presumably valuable handwritten Mahler manuscript, but it turns out to be a cheap copy only worth a few cents; so is a Schubert portrait inherited from his mother. Quickly he overcomes his devastation about the fraud and happily sells them to an American tourist at the flea market.

When Magnolia readily admits: "der Flug vom Kennedy Airport nach Wien-Schwechat erschien mir mittlerweile wie eine Art Zeitreise, die mich um hundert Jahre in die Vergangenheit zurückversetzt hatte" (WP 29), Faschinger enhances the strong ties with the past via strategies of spatial and temporal doubling and draws on prominent Viennese sites and sights, such as Doblinger's music shop and St. Stephen's Cathedral. Coincidentally, Aunt Pia's residence at the corner of Domgasse and Blutgasse is precisely the same location where Rosa murdered her husband. Yet the repetition also extends to criminal behavior of a serial rapist and to fleeting sensations provoked by simple gestures. For instance, Magnolia changes a light bulb in Aunt Pia's home, and

sah [ ... ] das müde und blasse Gesicht der jungen Rosa Tichy vor [sich], die sich an einem ockerfarbenen Samtvorhang zu schaffen machte, worauf mir 
schwindlig wurde und ich um ein Haar von der Leiter auf das Sternparkett des Vorzimmers gefallen wäre. (WP 198)

Both Josef and Rosa repeatedly seek approval of their actions from their late mothers; while Josef's mother rises from the dead in haunting nightmares, the legacy of Rosa's mother is passed on in her inheritance of the Goldene Hausfrauenbuch and Dobromila Rettigova's cookbooks, which she regularly consults.

Even the art of making love finds its double when the New Yorker John and the Czech Karel are both surprised that Magnolia and Rosa "[s]ich mit einer Unschuld hingegeben hätte[n], welche [sie] nicht nur rühre, sondern auch errege und mit einer mädchenhaften Scheu" rarely found among the women they know (WP 504). Schönbrunn Castle is the site of Magnolia and Josef's athletic ambitions, and its palm house surfaces in Rosa's script as a Sunday outing with Dr. Doblhoff while in the butterfly house young Josef had a homoerotic encounter with his tutor and later his first kiss with Magnolia. The biblical Hohelied Salomonis not only seals their love but also serves throughout the novel as a multigenerational declaration of platonic, heterosexual, and homosexual love, exemplifying Faschinger's masterful intertextual networking. Reminiscent of Thomas Bernhard's style are deliberate repetitions establishing linguistic links among her characters when they repeat entire passages. For example, Rosa notes "daß [sie] in unmittelbarer Nähe großer Wasserflächen für [ihre] Schwierigkeiten schneller und leichter eine Lösung fand, als andernorts" (WP 303). Almost fifty pages later this observation is repeated verbatim by Magnolia (WP 350).

These overlapping spatial and temporal settings create postmodern networks, some of which evolve from popular beliefs and an era when dreams clashed with harsh reality. And as Faschinger conveys in her interview with Gisela Roethke, Vienna 1900 in particular inspired her "ironic portrayal of popular myths." ${ }^{\prime 39}$ Perhaps the most notorious, surviving well into postwar and postmodern Vienna, is the Sisi cult. ${ }^{40}$ Faschinger fully exploits it in a variety of ways so that it assumes several narrative functions. When she writes "der Tod Sisis durch Selbstmord in Paris, die Ermordung Romy Schneiders durch einen italienischen Anarchisten im Jahre 1898 habe sich von Anfang an abgezeichnet" (WP 239), this obvious falsification points to another typical trait of "historiographic metafiction" when "certain known historical details are deliberately falsified in order to foreground the possible mnemonic failures of recorded history and the constant potential for both deliberate and inadvertent error." ${ }^{\text {41 }}$ Contrary to the aforementioned legacy of Lueger, an unwitting example of delusion, this inversion of facts is a conscious attempt at deception. In the course of the twentieth century, Sisi, the object of feminine mystique, has been immortalized in the film Sissi, die junge Kaiserin starring Romy Schneider, regularly broadcast on Austrian television. ${ }^{42}$ Sisi also plays a prominent role 
in Josef's dreams, representing either Magnolia or his mother, whose alleged beauty was compared to that of the star. Given their very different appearances, Magnolia finds this somewhat puzzling. Another myth originated in the film Der Dritte Mann, partly shot in Vienna's subterranean sewer system. However, long before the criminal in Der Dritte Mann brought it unprecedented acclaim by hiding there from the police, the system provided homeless Rosa with temporary shelter among the ragpickers. Coincidentally, both films are favorites of Aunt Pia, although the contrasts between the feminine beauty in the aristocracy and the reckless criminal and profiteer of the postwar era could not be any stronger. Nonetheless, they present paradoxical cultural paradigms that inform Vienna's historical-cultural discourse. Perhaps the wittiest overlap occurs in the Musikvereinssaal, another iconic place of Austrian culture known to millions because of the internationally broadcast New Year's Day concert with the Vienna Philharmonic. While this event attracts national and international dignitaries, regular concerts also have their fair share of prominent guests. Thus, not surprisingly, in Wiener Passion Rosa catches a glimpse of Kronprinz Rudolf and Magnolia sees the Bundespräsident. When their eyes meet, both women "senkte[n] diskret die Lider" (WP 486).

Contrary to her bashful heroines, in an ironic yet direct manner Faschinger looks straight into the golden Viennese heart and uncovers a city deeply rooted in the past, filled with cultural treasures and a less flamboyant "other" side. She critically engages the workings of space and time to trace a gradually changing city in spite of and by means of its rich history and culture and shows how it maintains and reinvents itself as a cultural territory. Wiener Passion also revives the idea of the city as a magnet for immigrants, whose motivations to settle there are multifaceted and who form a plurality that narratively translates into voice ensembles and an urban mosaic. These heterogeneous ensembles intertwine past and present, the familiar and the little known, the mundane and the unique. In sum, with Wiener Passion Faschinger has commented in a witty and most entertaining way on two fin-de-siècle spaces, drawing on historic-cultural myths and realities.

I would like to thank Katherine Arens and Maximilian Aue for helpful comments on my talk on Lilian Faschinger and postmodern writing at the 2003 meeting of the Modern Austrian Literature and Culture Association. A revised version of this talk was presented at the 2005 meeting of the German Studies Association.

${ }^{1}$ This list is far from complete. For further inspiration see for instance Katharina Riese, The Making of Vienna. Literarische Stadtführerinnen durch Wien. (Wien: Löcker, 2003). She traces Vienna in Claudia Erdheim's So eine schöne Liebe, Elisabeth Reichart's Nachtmär, and Marlene Streeruwitz's Verführungen. Also see Monika Sommer, Marcus Gräser, Ursula Prutsch, ed., Imaging Vienna: Innensichten, Außensichten, Stadterzählungen. (Wien: Turia + Kant, 2006), especially Daniela Strigl »Stadt im fetten walfischbauch« Wien Bilder in der zeitgenössischen Literatur, 122-37. Also see Wendelin Schmidt-Dengler, "Die Hypothek der Geschichte: Der ganz normale Wahnsinn in Wien: Zu neuen Romanen von Eva Menasse, Peter Rosei und Gerhard Roth." Literaturen: Das Journal für Bücher und Themen 4 (2005): 55-58. 
${ }^{2}$ For the history of multicultural Vienna see Michael John, "Mosaik, Schmelztiegel, Weltstadt Wien? Migration and multikulturelle Gesellschaft im 19. und 20. Jahrhundert.” Wir. Zur Geschichte und Gegenwart der Zuwanderung nach Wien. (Wien: Eigenverlag der Museen der Stadt Wien, 1996) 137-44.

${ }^{3}$ In "America and the Newest Jewish Writing in German." The German Quarterly 73.2 (Spring 2000) 151-62, Sander Gilman reads Vienna as "the place of testing of 'real' Jews" (158), specifically in Rabinovici's short story collection Papirnik. The story "Der richtige Riecher," for instance, exemplifies a radical break with traditions when a Polish-Jewish mother encourages her son Amos, a native of Vienna, to respond physically, not just verbally, to anti-Semitic insults. After his best friend's repeated provocations, Amos punches him in the face and breaks his nose. This action challenges what the son in Robert Schindel's film Gebürtig has been specifically taught is taboo behavior in the 1930s: "Hauen ist nicht jüdisch." In the novel of the same title, the Holocaust survivor Herrmann Gebirtig reluctantly returns to his hometown of Vienna to testify in a Nazi war crimes trial. Once there, he walks around in his childhood neighborhood like a blind man eager to feel every single brick so that he can come to terms with his past and his past in this city. Overwhelmed by memories, he even considers buying an apartment in Vienna, a plan that fails after the not guilty verdict for the Nazi criminal makes him instantly leave for New York.

${ }^{4}$ Lilian Faschinger, Vienna Passion (London: Review, 2000) 30.

${ }^{5}$ For a nuanced reading of the outer districts as urban jungles see Wolfgang Maderthaner and Lutz Musner's insightful Die Anarchie der Vorstadt: Das andere Wien um 1900. (Frankfurt am Main, New York: Campus, 2000). 1988) 4.

${ }^{6}$ Linda Hutcheon, The Poetics of Postmodernism. (New York, London: Routledge,

${ }^{7}$ Judith Ryan, "Fictionality, Historicity, and Textual Authority: Pater, Woolf, Hildesheimer." Neverending Stories. Toward a Critical Narratology. Ed. Ann Fehn, Ingeborg Hoesterey, and Maria Tatar. (Princeton, N.J.: Princeton U P, 1992) 45-61, here 58.

${ }^{8}$ For more on "Wien [ . . ] als die größte tschechische Stadt" and Czech immigration see Monika Glettler, "Tschechen und Slowaken in Wien." Wir. Zur Geschichte und Gegenwart der Zuwanderung nach Wien. (Wien: Eigenverlag der Museen der Stadt Wien, 1996) 137-44, here 10 . There is a remarkably high proportion of servants among immigrants, and according to Michael John, “'We Do Not Even Possess Our Selves': On Identity and Ethnicity in Austria, 1880-1937." Austrian History Yearbook 30 (1999) 17-64, about 50 percent came from Bohemia and Moravia (30). While the sought-after Bohemian cook for Viennese families is legendary, lesser known is the actual newspaper for domestic servants (Ibid., 40, 41).

${ }^{9}$ Hutcheon, The Poetics of Postmodernism 225.

${ }^{10}$ In "Einleitung: Die Signaturen der Wiener Moderne." Paradigmen der Moderne. Ed. Helmut Bachmaier. (Amsterdam, Philadelphia: John Benjamins Publishing Company, 1990): vii-xxiii, Helmut Bachmaier sees the Dienerfigur paradigmatic for the fin-de-siècle embodying "die zeremonielle Selbstauslöschung des Ich . . . und die Auratisierung der Tilgung des Selbst" (xiii).

${ }^{11}$ Rosa's resolve is not the least bit shaken after she befriends the activist Ljuba, founder of a short-lived newspaper geared toward improving the working conditions of servants, outspoken supporter of the National Czech movement, and later U.S. immigrant who takes Rosa's child, Aphrodite, with her.

${ }^{12}$ See Maria-Regina Kecht, "Geschichten aus der Truhe holen. Macht und Ohnmacht in <Wiener Passion〉." Script 19 (February 2001) 24-31.

${ }^{13}$ Lilian Faschinger, Wiener Passion. (München: DTV, 2001) 180. In the following, Wiener Passion will be abbreviated as WP in parenthetical references.

${ }^{14}$ Klaus R. Scherpe, "Modern and Postmodern Transformations of the Metropolitan Narrative.” New German Critique 55 (Winter 1992) 71-85, here 82.

${ }^{15}$ The rock musical Freudiana (music by Eric Wolfson and the Alan Parsons Project) premiered at Theater an der Wien in Vienna on December 19, 1990.

${ }^{16}$ Gisela Roethke, "Lilian Faschinger im Gespräch.” Modern Austrian Literature 33.1 (2000) 84-103.

${ }^{17}$ Michel de Certeau, "Walking in the City." The Practice of Everyday Life. Trans. Steven F. Rendall. (Berkeley, Los Angeles, London: U of California P, 1984) 91-110.

${ }^{18}$ Hutcheon, The Poetics of Postmodernism 114, my emphasis. 
${ }^{19}$ Ibid., 108.

${ }^{20}$ Simon Malpas, The Postmodern. (London, New York: Routledge, 2005): 24.

${ }^{21}$ See also Alexander Gelley's thought-provoking article, "City Texts: Representation, Semiology, Urbanism." Politics, Theory, and Contemporary Culture. Ed. Mark Poster. (New York: Columbia U P, 1993) 237-60.

${ }^{22}$ Peter Stallybrass and Allon White, "The City: The Sewer, the Gaze and the Contaminating Touch.” The Politics and Poetics of Transgression. (Ithaca, New York: Cornell U P, 1986) 125-48, here 126. Highly recommended also is Hubert Ch. Ehalt, Gernot Heiss, and Hannes Stekl, ed., Glücklich ist, wer vergißßt? Das andere Wien um 1900. (Wien: Böhlau, 1986).

${ }^{23}$ Malpas, The Postmodern 6.

${ }^{24}$ Brian McHale, Postmodernist Fiction. (London, New York: Routledge, 1987).

${ }^{25}$ Malpas, The Postmodern 24, referring to McHale.

${ }^{26}$ Ibid., 25.

27 Thomas Rothschild, "Horvath, Brown und Havelka." Die Presse 15498 (16 October

1999) VII; Ulrich Weinzierl, "Kakanisch ist die Kokotterie. Beschreibungswütig: Lilian Faschingers Wiener Passion.” Frankfurter Allgemeine Zeitung 295 (18 December 1999) V.

${ }^{28}$ Franz Haas, "Wien in Hülle und Fülle. Doppelt endzeitlich: der neue Roman von Lilian Faschinger." Neue Zürcher Zeitung 48 (26 February 2000) 35.

${ }^{29}$ Ellie Kennedy, "Identity through Imagination: An Interview with Lilian Faschinger." Women in German Yearbook. Feminist Studies in German Literature and Culture 18. (Lincoln: U of Nebraska P, 2002) 84-103, here 24.

${ }^{30}$ Hutcheon, The Poetics of Postmodernism 133.

${ }^{31}$ Roethke, "Lilian Faschinger im Gespräch" 95; Kennedy, "Identity through Imagination: An Interview with Lilian Faschinger" 22.

${ }^{32}$ Hutcheon, The Poetics of Postmodernism 113-14.

${ }^{33}$ Roethke, "Lilian Faschinger im Gespräch" 97.

${ }^{34}$ De Certeau, "Walking in the City" 97.

${ }^{35}$ Ibid., 108 .

${ }^{36}$ Lefebvre qtd. in Gelley, "City Texts: Representation, Semiology, Urbanism” 241-42.

${ }^{37}$ In the 1995 novel Magdalena Sünderin (München: Deutscher Taschenbuch Verlag, 1997), Faschinger makes numerous references to Austrian cuisine, including a wide range of meats and sweets from "Linzer Auge" to "Pischinger-, Sacher- und Doboschtorten" (63). It is somewhat disappointing that nobody in Wiener Passion has a tooth for Vienna's world-renowned sweets, from Gustav and Wilhelm Heller's Original Wiener Zuckerl and Casali Rum Kokos to Manner with the logo of the Stephansdom imprinted on each package, not to mention Heindl's Sissi Taler and Sissi Veilchen, or Hofbauer's Sissi Kugeln.

${ }^{38}$ De Certeau, "Walking in the City" 91.

${ }^{39}$ Roethke, "Lilian Faschinger im Gespräch" 98.

${ }^{40}$ For more on the fascinating empress see Lisa Fischer, Schattenwürfe in die Zukunft: Kaiserin Elisabeth und die Frauen ihrer Zeit. (Wien, Köln, Weimar: Böhlau, 1998).

${ }^{41}$ Hutcheon, The Poetics of Postmodernism 114.

${ }^{42}$ The spelling in Faschinger's novel differs from that traditionally used in the film trilogy consisting of Sissi (1956), Sissi, die junge Kaiserin (1956), and Sissi, Schicksale einer Kaiserin (1957). 